\title{
De Cantinas, Vapores, Cines y Discotecas. Cambios, Rúpturas e Inercias en los Modos y Espacios de Homosocialización de la Ciudad de México
}

\author{
About bars, saunas, cinemas and discotheques. \\ Changes, Ruptures and Inertia in Homosocialization Modes and Spaces in \\ Mexico City
}

\author{
Renaud René Boivin \\ Instituto Francés de Urbanismo \\ renoboivin@yahoo.esr
}

\section{Resumen}

Este artículo trata de la construcción, entre los años 40 y 70 , de los espacios de encuentro entre varones que mantienen relaciones sexo-afectivas con otros varones en la ciudad de México. En oposición a una visión lineal y reduccionista de la historia de dicha construcción, que tiende a ubicar en el presente y en el desarrollo del comercio gay un avance progresista y liberador respecto del pasado reciente, de represión política y social de la homosexualidad. A través de memorias, crónicas, creaciones literarias y entrevistas a profundidad con activistas gays, observamos hilvanarse en el espacio urbano y el tiempo histórico, las vidas de distintas generaciones de 'homosexuales' que forman 'el ghetto gay' capitalino; lugares y pautas de socialización y encuentro que formalizan una tradición propia al ofrecer tanto la continuidad espacial como la inercia de los modos de encuentro social y sexual de los 'homosexuales'. Tras matizar pues el aspecto liberador de esos espacios de homosocialización especializados, ligaremos su desarrollo con la pérdida y la búsqueda (siempre renovada, hasta la actualidad) de contigüidad social, ésta rompiéndose a medida que se multiplican e individualizan, las formas de experimentar la sexualidad, las prácticas culturales y urbanas dentro de la misma población homo/bisexual capitalina, según las edades, las clases sociales, las posibilidades y aspiraciones económicas y los lugares de residencia de ésta.

Palabras clave: homosocialización; clases; comercio; espacios de encuentro; ghetto.

\begin{abstract}
This work is about the construction of socialization spaces for men which have love and sex with other men in Mexico City, between the 40s and 70s. In opposite to the lineal and reductionist vision of the history of this construction, that tends to recognize in the present and in the development of gay trading a sign of liberation in rupture with the recent past, made of social repression and invisibility. Based on memories, chronicles, literary creations and interviews with gay activists, the article observes a basting between urban space and historic time and the lives of the various generations of 'homosexuals' that have composed the Mexican capital's 'gay ghetto'. The development of specialized homosocialization spaces is bound with the loss and the search (which is in continual renovation, even nowadays) of social contiguity, that is progressively broken by the multiplication and individualization of forms of expressing sexuality, and by cultural and urban practices, according to ages, social classes, socio-economical possibilities and aspirations, and neighborhoods.
\end{abstract}

Keywords: homosocialization; social classes; commerce; meeting spaces; ghetto 


\section{Introducción}

En este trabajo estudio la evolución de los espacios de encuentro entre varones entre mediados de los años 40 y finales de los 70. Se parte de una visión constructivista del homoerotismo: las relaciones homoeróticas se construyen desde posiciones sociales y lugares concretos y su definición -acotación- como 'homosexualidad' viene ligada a la emergencia de nuevas clases urbanas en la era moderna, así como a las transformaciones en las formas de relacionamiento y socialización que van emparejadas con la urbanización e industrialización. Por otra parte, se entiende que existen 'culturas homoeróticas' distintas según los grupos sociales y experiencias locales de la sexualidad, las cuales incluyen definiciones, normas, prescripciones y prohibiciones acerca de las actividades y roles que cada persona, según su género y edad, debe desempeñar. Utilizo por tanto la noción de 'homosocialización' ya que ésta posibilita poner entre paréntesis la identidad presumida de quienes frecuentan los distintos lugares de encuentro y socialización. Se hablará de 'lugares de encuentro entre varones' más que de 'lugares gays' por dos razones fundamentales. Primero, al ampliar la noción a todos los lugares de socialización entre varones, podemos observar la evolución histórica de estos evitando los anacronismos y alejándonos de las interpretaciones identitarias. Segundo, de este modo podemos enfocar hacia los procesos de construcción de estos espacios en relación con las sexualidades masculinas, sus vínculos con las prácticas e identidades sexuales, sin prender la categoría gay como única y unívoca en este largo proceso lleno de retrocesos y variaciones.

\section{Los Lugares de Homosocialización}

Para el estudio de los vínculos entre homoerotismo, espacios y clases sociales, consulté fuentes variadas: entrevistas a militantes del Archivo del Movimiento Homosexual en México del CIDHOM$^{1}$, testimonios, memorias, crónicas y biografías, obras de literatura, revistas y guías gays. A este corpus se añaden entrevistas y observaciones de campo. Además, revisé la información de las publicaciones académicas existentes sobre los gays de la ciudad de México, sus prácticas y sus espacios ${ }^{2}$. Con este material se llevó a cabo un análisis histórico y sociológico de la evolución de los espacios de homosocialización a lo largo del siglo XX, determinándose así distintos períodos. La formación de un 'gueto's homosexual remonta al porfiriato, si bien éste se limitaba a unos individuos de los sectores más pudientes, quienes se reunían y tenían prácticas sexuales en baños exclusivos de la ciudad (MACÍAS, 2004) y en fiestas privadas. Entre 1920 y 1940 se sitúa la primera etapa de consolidación de un ambiente gay diferenciado. Los homosexuales se reúnen en espacios exclusivamente masculinos o mixtos, algunos marginales como las cantinas de la Plaza Garibaldi, otros frecuentados por grupos privilegiados de la ciudad. El ligue entre varones y la prostitución masculina se concentran en la calle, en especial en la Alameda, en San Juan de Letrán y en la calle Plateros (hoy Madero). De día, suelen almorzar y tomar café en las calles del Ayuntamiento, y atrás, cerca de la 'zona roja', en la plaza Vizcaínas y calle Regina.

Progresivamente aparecen los primeros bares frecuentados y regentados por gente homosexual. En los años 40 y 50 , es notable el desplazamiento del centro de actividad económica desde el actual Centro Histórico hacia Reforma y Chapultepec, coincidiendo con el reforzamiento de las dinámicas de expansión y crecimiento de la ciudad, de aumento de la segregación urbana de actividades y residencias así como de diferenciación de los lugares de esparcimiento. Los espacios de homosocialización se especializan entonces en términos de ambientes ofrecidos y públicos atendidos, y los varones quedan cada vez más separados según su posición socioeconómica. En los años 1970, la apertura de establecimientos destinados específicamente a una población gay está ligada a un proceso anterior y de larga duración de diferenciación social y espacial más amplio. Nuevas formas de sociabilidad homoerótica van superponiéndose a las más antiguas, sin substituirlas del todo. Es sobre este proceso, de doble alejamiento geográfico y social del centro popular y de formas más tradicionales de entender y vivir el homoerotismo que versará este trabajo.

\section{Ruptura con la Familia y Nueva Vida Doméstica}

A partir de las biografías de algunos militantes gays de la ciudad de México nacidos en los años 40 y $50^{4}$, podemos atravesar sus espacios de vida y formas de socialización. Sus entrevistas evidencian que, en contradicción con la idea común, la generación que propiciará la salida colectiva del clóset en los 70 no padeció una represión tan brutal como a veces se cuenta. Es con una preocupación política más amplia que buena parte de los militantes decide formar parte del movimiento: se va a librar batalla en demanda de una mayor participación social; para dar otra imagen del homosexual, combatiendo el estigma que le condena a la marginación. Los entrevistados subrayan

Renaud René Boivin 
principalmente las extorsiones de la policía, la falta de seguridad, la discriminación, las burlas homofóbicas en la escuela y en el ámbito laboral. Pocas veces se mencionan conflictos fuertes en las familias de clase media, más aún tratándose de sectores ligados a un capital cultural alto:

Yo realmente nunca viví, ni de niño, ni de púber, ni de adolescente, lo que se puede llamar un conflicto para aceptar mi homosexualidad como cuestión trágica en absoluto (...). Simplemente ellos conocen mi vida, mis amigos, mis lecturas. (Mondragón, profesor, militante del FHAR).

Esta generación no rompe tanto con la represión, sino con la ocultación, a menudo ligada a los valores tradicionales de la clase media, al 'silencio discreto' y burgués en el cual se ahogaban los militantes: "antes no se podía hablar de homosexualidad; no lo podías mencionar, era de mal gusto, incluso, para decir algo en contra de ella. Ahora se habla, se ve en las familias", explica González De Alba.

El silencio, había que liberarse del silencio, de un silencio impuesto, (...) era un silencio impuesto que se volvía clandestinidad. Antes del movimiento la clandestinidad era completa, no era lo que ahora llamamos invisibilidad (...). La clandestinidad es la convicción de esconder como una forma de protección pero incluye estrategias de ocultamiento (...) incluía actitudes como lo hacen los refugiados. (Max MEJÍA, militante del grupo Lambda).

Los militantes nacidos en provincia expresan en cambio una realidad más dramática en cuanto a la relación con sus padres y sus orígenes: "Ante el rechazo inicial de mi padre, mi madre y mis hermanos, me revelé. Desde los 14 o 15 años empecé a ocultar mi vida, a vivir una vida pública gay sin que ellos supieran (...). Ellos me rechazaron, ahora yo los rechazo, yo vivo mi vida", explica Braulio Peralta. En múltiples ocasiones, la movilidad geográfica desde ámbitos culturales más tradicionales alienta un fulminante ascenso social inter-generacional. Los migrantes suelen romper con los modos de vida de sus padres de forma más categórica y tienden a tener una mejor posición social que ellos. Esta ruptura, más fuerte con el alejamiento geográfico, se vincula directamente con las nuevas posibilidades de desarrollo personal y sexual de la ciudad para el varón originario de un medio social tradicional y machista.
Así sea en los años 20 o en los 60, la capital representa una especie de salvación para los varones homosexuales provenientes de provincia ganosos de 'vivir la vida': "Antes me refrenaba a darle gusto a mis instintos y me sentía cohibido (...). Ya entre los quinientos y seiscientos mil habitantes me sentí más libre" describió Nandino (2000). "Yo, por ejemplo, soy de Tuxpan, Veracruz. Si me hubiera quedado allí ahorita sería una persona distinta de la que soy en el D.F., por veinte mil razones", explica Peralta. "Entonces decidí romper con la familia y me fui al D.F. a estudiar con la intención, además, de descubrir otras maneras de vida”, relata Sergio Santamaría, mientras Eli Bartolo evoca su llegada a México como una 'liberación familiar', una 'ruptura' con la 'opresión'.

\section{Recomposición y soltería}

Como bien subrayaba Monsiváis (2007) la construcción moderna del homoerotismo, como identidad sexual asumida, ha dependido de la formación de grupos, es decir, de un gueto, productor de identidades colectivas y de estilos de vida compartidos. "Muchos nos refugiamos en el gueto" confirma Eli Bartolo. El gueto es una reserva de recursos sociales para integrarse, encontrar empleo, ascender. Una manera, quizás, de soportar la soledad. En grupo, los homosexuales tejen lazos aparentados a los familiares: "Nos inventamos esas familias fantásticas que los heterosexuales no acaban de entender, ni entenderán en mucho tiempo, esas familias que tú escoges" asume Tito Vasconcelos, originario de Oaxaca. Inventan nuevos modos de vivencia doméstica: muchos comparten departamento entre amigos, quedan a diario para ir al cine o al teatro, trabajar, salir por la noche, ligar y tener sexo. La soltería es una condición para la participación al gueto homosexual, la inestabilidad un estilo de vida en clara oposición respecto del modo de vida familiar, tradicional, de pequeña burguesía urbana o provinciana, de sus raíces. Al igual que la generación anterior, los jóvenes homosexuales de los años 60 se juntan en sus domicilios, y a las reuniones casi diarias en las casas de los Contemporáneos se suceden las fiestas de disfraces de Wencho Mont y Morley Webs, en las cuales se reúne todo el ambiente; siguen estableciéndose contactos entre generaciones y sectores sociales en los apartamentos Windsor, donde vivían artistas, intelectuales, actores y bailarines gays:

A partir de ese lugar me conecté con David Antón y Wilberto Cantón, que tenía un departamento en Reforma, por donde está el Excélsior. David Antón tenía un

\section{Renaud René Boivin}




\section{departamento en Madero, entre Bolívar e Isabel La Católica. (...). Ahí conocí a Salvador Novo, él iba mucho. (J.J. HERNÁNDEZ).}

Sin compromisos sociales, muchas veces desligado de su medio social de origen, en aquel entonces el homosexual está condicionado a una eterna soltería, y el vagabundeo continuo en busca de nuevas aventuras es el destino propio de muchos varones que 'viven la vida'. De recepciones en fiestas, de concursos de disfraces en 'escenas' callejeras, la nueva generación de homosexuales forja su propio sistema de valores, sus leyes de mercado, su sistema de ayuda mutua, moviéndose entre la marginalidad clandestina del sexo y los lugares mixtos de moda.

\section{Los Ferrocarrilleros del Vapor}

Los baños de vapor también facilitaban el encuentro homoerótico. Fueron lugares de encuentro entre varones provenientes de todos los estratos sociales desde hace mucho tiempo: desde los Baños de la Lagunilla, cerrados en 1905 por falta de clientela debido al aumento de precios, pasando por la Alberca Pane, en Reforma, a finales del siglo XIX, frecuentada por un público de clases superiores, hasta los populares vapores de la Avenida Hidalgo, frente a la Alameda Central. Novo evoca sus visitas de vapores desde Ruturn Ticket (1928), Nandino menciona una primera incursión en 1940 en los Baños El Chopo, cerca de su casa, donde "se asearon con distinción la aristocracia y la prole del barrio" (MULIA, 2012).

En varias ocasiones trató los esguinces de Novo tras alguna caída de éste en los baños turcos. Asimismo, comenta que otro médico del Hospital Juárez, a quien

Mapa 1. Primera Especialización y Desplazamiento de los Lugares de Residencia y Homosocialización en la Ciudad de México, 1940-1955. también le encantaban los muchachos (sic), le informa de la existencia, en la Merced, de los denominados 'baños del montón', donde "iban boleros, vendedores ambulantes, mecánicos, barrenderos, en fin, de todo -en los que había un masajista que estaba guapo" (AGUILAR, 1986, p. 105). La experiencia de Nandino, que en varias ocasiones conoce a sus parejas en baños de vapor, donde admira los cuerpos fuertes y esculpidos por el trabajo manual, no debe ser aislada. Como él, otros médicos, letrados y empleados, habrán frecuentado aquellos baños públicos, donde el encuentro también se daba entre clases sociales, entre culturas sexuales cada vez más distanciadas en el resto de los ámbitos urbanos. En los años 40 y 50, se construyen nuevos baños con instalaciones más modernas: los Baños Mina (en la calle Mina, inaugurado en 1958), los Ecuador (en el número 14 de la calle del mismo nombre, atrás de la Plaza

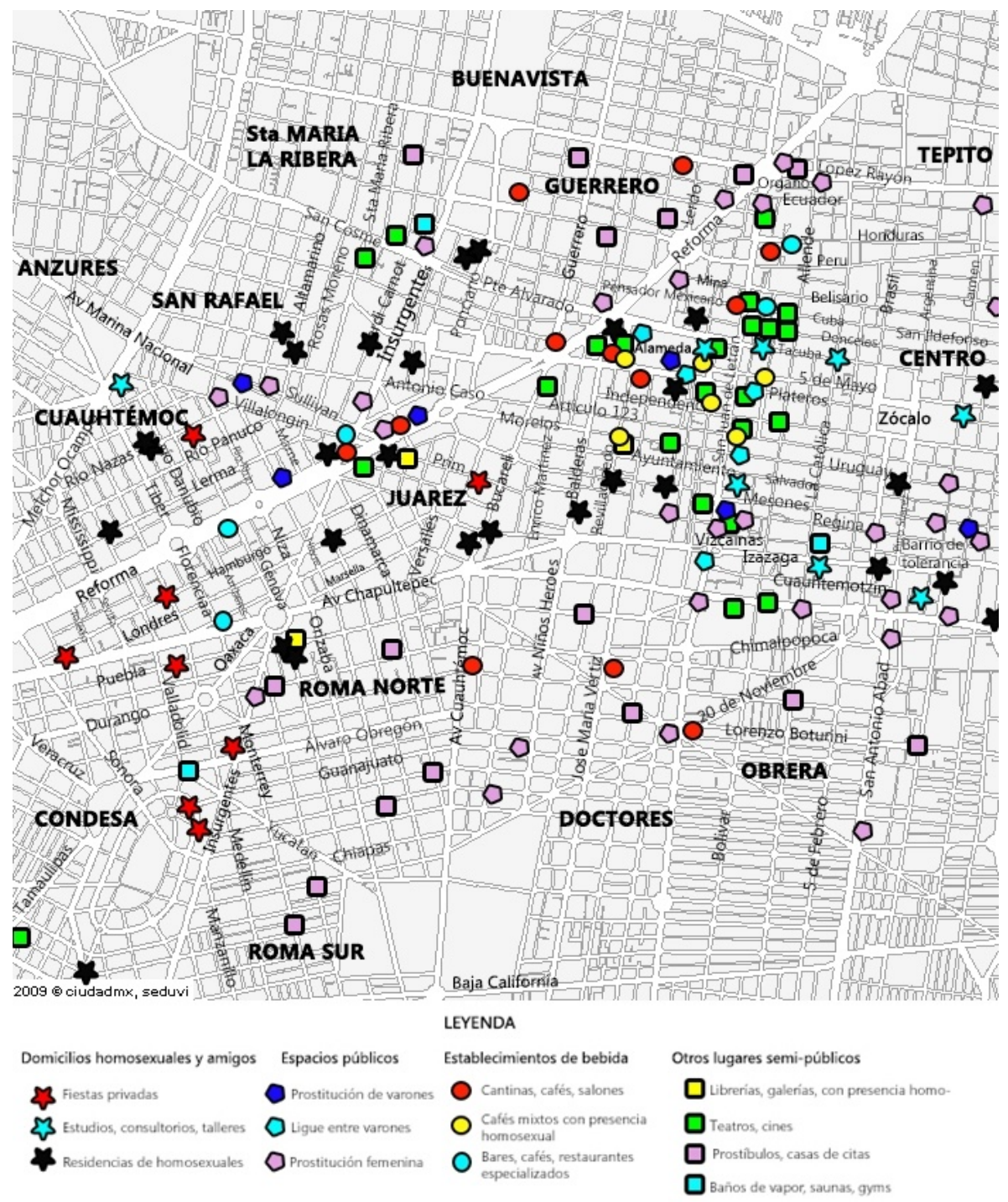

Renaud René Boivin 
Garibaldi), San Juan (Calle López, atrás del Cine Teresa), entre otros. Quizás deban su éxito a la misma ausencia de espacios en los años 60 debido a la depresión y al abandono de las zonas donde se ubicaban. Al perder clientela, los baños fueron progresivamente cambiando de función, alcanzando su punto álgido de popularidad como sitios de encuentros sexuales en los años 70.

\section{Cines, Cafés y Calles como Incendios}

Al igual que en los años 20 y 30 , en los 50 y 60 los homosexuales se reunían principalmente en lugares públicos mixtos tales como teatros, cines y cafés. En los años 40 y 50, especialmente en los teatros 'Lírico' y de Bellas Artes, confluyen artistas, escenógrafos, directores, pintores, literatos homosexuales mientras que las vedettes y mecenas organizan fiestas en sus casas y atraen a sus amigos bohemios en salones y clubs de alta categoría. Los cines son tradicionalmente sitios de socialización y encuentro entre varones: Nandino (2000, p. 82) refiere que conoció a Jaime Torres Bodet a mediados de los 20 en el 'Cine Venecia', que ya tenía 'mala fama', "cambiando más de asiento que interesándose en las películas", mientras que Xavier Villaurrutia evoca relaciones homoeróticas, entre llantos y a oscuras ('De Cinematógrafo', en Reflejos, 1926, citado por MONSIVÁIS, 2006).

El declive de los cines tradicionales a partir de los 50 conllevará su transformación en cines eróticos (ALFARO y OCHOA, 1997), los cuales derivaron rápidamente en cines de sexo homosexual. Los cines Colonial y Nacional en Fray Servando Teresa de Mier, Mitla en San Cosme, Apolo en la Plaza Vizcaínas; los cines Teresa (inaugurado en 1924, clausurado y abierto de nuevo tras modernización en 1940), Savoy, Mariscala, Cineac y Cinelandia ${ }^{6}$, a lo largo del actual Eje Central Lázaro Cárdenas. Este último era "frecuentado por pederastas con dizque aspecto de señores respetables, que, si estabas solito, se sentaban en la butaca próxima, se 'hacían los disimulados' (...) y de pronto aventuraban la mano sobre uno de tus muslos y en avance hacia tu pito (...). La leyenda negra pretendía que si uno era deseado por un joto, uno resultaba sospechoso de jotez". (José DE LA COLINA, 2011).

En otras colonias como la Roma, San Rafael, Santa María La Ribera, Del Valle, los cines, los urinarios de algunos edificios públicos y los baños de vapor, propiciaban el encuentro, atrayendo además en sus cercanías juegos de miradas y toqueteos. No era nada inusual tampoco que dos hombres se sedujeran en la calle: la Avenida San Juan de Letrán conservaba su tradicional función de nervio central de la vida homosexual, irrigando la Alameda Central y sus entornos, sitios tradicionales de ligue callejero entre varones:

En el centro había un corredor de ligue que era Madero, tarde y noche. Lo que es Juárez y La Alameda era un corredor precioso, de intercambios de conocimientos de la gente. Había una pérgola preciosa enfrente de La Alameda, ahí en donde está el monumento al guagüis [sexo oral]. (J-J. HERNÁNDEZ).

En esta zona también se prostituían algunos hombres, por lo general jóvenes y de apariencia varonil -un mercado prostitucional que podía alimentarse de los migrantes de provincia recién llegados a la ciudad que se instalaban al norte del viejo centro. Así pues, si bien todavía predominaba el ocultamiento y la discreción en las relaciones sexo afectivas entre varones, también existía cierta facilidad para establecer contactos en la misma calle o en espacios públicos:

Te ibas a eso, podías irte caminando en las calles, caminando encontrabas una persona y la ligabas, no había problemas. Tenías relaciones, te ibas a la vuelta, te ibas a unos baños (...). En la actualidad ya no puedes hacer eso porque te sale que es asaltante. Yo en el coche ligaba mucho, ahora ya no lo puedo hacer. (Jorge CRUZ, comerciante, propietario de la discoteca Spartacus).

El Teresa era muy popular, тиу, тиу popular con mucho ajetreo (...). El Sanborns del Ángel era la capital del ligue $y$ (...) las calles ahí alrededor, el circuito infernal de Baja California por Insurgentes y vuelta por Aguascalientes por atrás del Sanborns, todo eso, por ahí pasaban cadenas de autos y ahí se cerraba el circuito mágico porque ahí desaparecía uno así [chasquido de dedos]. (Max MEJÍA)

\section{La Marginalidad en el Centro: cantinas, cabarets y salones}

Desde mediados de los años 20 y hasta principios de los 50, el ambiente se mueve entre las tradicionales cantinas de la Plaza Garibaldi, los centros nocturnos de moda de la Colonia Guerrero y los cabarets de la bohemia capitalina en la Colonia Doctores y Lorenzo Boturini. San Juan de Letrán y las calles que hoy 
conforman el eje central, la calle Cuauhtémotzin, unían Tepito al norte con la zona roja al Sur y el barrio de Cuauhtémotzin (NOVO, 1967) y La Merced (RODRIGUEZ, 1991).

Estos ejes también concentraban una parte de la oferta de ocio nocturno, la cual se iba expandiendo siguiendo el Paseo de Reforma hacia Las Lomas de Chapultepec al noroeste, y hacia el Sur por la Avenida de los Insurgentes, salpicada de salones y cabarets. Por otra parte, en los años 40 y 50, la colonia Roma llegó a concentrar decenas de burdeles, casas de citas, y demás sitios de sexo y prostitución. La casa de la Bandida, en Durango $\mathrm{n}^{\circ} 47$, casi esquina con Insurgentes, fue una de las más famosas. En la misma zona, Agustín Lara acudía a Las Mexicanitas, cerca de su domicilio. En algunas casas de las colonias Doctores y la Obrera trabajaban, también, varones afeminados. En otras se retransmitían los primeros materiales pornográficos (LEAL et al, 2005).

Los residentes de estas zonas paseaban en coche o caminaban por los camerinos de la Avenida Veracruz y la actual Avenida Obregón, las calles de Puebla y Orizaba, donde se podía ligar discretamente, en una banca o en un café, en una exposición de pintura o enfrente de un escaparate. En el cabaret Leda (Avenida Vertiz $n^{\circ} 118$ ), propiedad de Clotilde Ortiz Rubio, animado por el excéntrico y elegante Luis Aguado, llamado 'el Príncipe', se reúnen periodistas, artistas y músicos (Carlos Chávez, Agustín Larra, Diego Rivera) y demás amigos de María Izquierdo, escritores bohemios y extranjeros así como personalidades homosexuales tales como Chucho Reyes, Roberto Montenegro, Novo, Nandino, Rodríguez Lozano. Según Armando Jiménez (1991) la presencia de María Izquierdo, apreciada por su modo 'provinciano y folklórico', atraía "peladitos, albañiles, sastres, mecánicos, boteros y carpinteros, incluso conductores de tranvías, luego que concluían sus labores" en el depósito cercano.

Al norte del primer cuadro, por las calles de Donceles y Comenfort, se ubicaba entonces la zona de hoteles y pensiones donde, desde la Revolución, se alojaban estudiantes, militares, políticos y periodistas en sus visitas o estancias en la ciudad. Ya a principios del siglo los militares iban a admirar a María Conesa, en el Teatro Lírico, según recordaría Agustín Lara: “en su primer día en la Ciudad de México, todo soldado revolucionario cumplía dos anhelos largamente acariciados: uno, ir por la mañana a postrarse ante María Guadalupe, en el Tepeyac; y otro, ir por la noche al teatro a conocer a María Conesa".

Al oeste, por la Estación de Buenavista, en la colonia Guerrero, de provincia llegaban migrantes solteros en busca de promoción social: alrededor se asentaban restaurantes, tabernas, hoteles de varias categorías, prostitutas, algunas pocas cantinas. En la Plaza Garibaldi se juntan los homosexuales de clases acomodadas con los mariachis y grupos populares de la ciudad: "Por las noches, a la hora de la despedida, nos cortábamos los parranderos y nos íbamos al Salón México, al Plata Azul, al Tenampa y a todos los sitios donde había vino, canto, golfos y oportunidades", recuerda Nandino (2000, p. 61). A un costado, en Las Adelas $^{7}$, podían seguir el descenso por los barrios bajos hasta altas horas de la madrugada, junto con turistas, militares y travestis (MONSIVÁIS, 2002).

Cerca, se encontraba el Salón México - decorado por José Gómez, alias 'El Hotentote' - dividido en tres pisos según el nivel socio-económico de la asistencia (NANDINO, 2000). Acudían homosexuales de clase media, pintores, músicos, intelectuales, poetas, que podían así ir y venir de un nivel a otro, pasar de un ambiente popular a la exclusividad de los más privilegiados, y por tanto conocer varones de clases más bajas, cuyas figuras a menudo correspondían al ideal de masculinidad deseado por los 'homosexuales' de la época. Así Manuel Rodríguez Lozano, por ejemplo, quien ligaba tanto con "soldados y chóferes que él levantaba en un antro de mala muerte en Garibaldi" como con alumnos y 'mozos' (ayudantes) en la escuela de pintura, de origen obrero y popular Abraham Ángel, Tebo o Nefeno - a quienes introducía en temas plásticos (ZAMORANO, sin fecha). Ahora bien, según Nandino los 'machos' eran siempre 'presa fácil'. El médico cuenta que "sacó varias veces a unos golfos" en los cabarets a los que iba a menudo con Xavier Villaurrutia, “a base de pura plática y de invitarles algunas copas. A pesar de que estaban con sus mujeres, nosotros les hacíamos interesante nuestra compañía.” (AGUILAR, 1986, p. 117).

\section{Masculinidad y Relaciones Sexo - Afectivas Interclasistas}

Los espacios tradicionales de encuentro y socialización entre varones, en especial las cantinas y los baños de vapor, ofertaban a su clientela 'homosexual' un ambiente masculino ${ }^{8}$, donde era posible hallar el tipo de relación deseada. El poder adquisitivo permitía la elección del amante entre la asistencia de bajos recursos. Casi todas las relaciones que tuvo Nandino, iniciadas en baños de vapor, en cantinas y en la calle, repiten básicamente el mismo esquema: sus parejas provienen de clases bajas; el médico les introduce al mundo homosexual; presta ayuda material a sus familias e incluso obsequia casa a algunos. Nandino, consciente de la distancia que le separa, culturalmente de sus novios, pretende incluso

Renaud René Boivin 
educarles:

Invertí bastante en descubrirle que había culturas distintas, con diferentes colores, olores y sabores, pero finalmente conseguí lo más importante: convencerlo de que también había otra clase de amores, por ejemplo el de un hombre por otro, sin desprestigio para la hombría de ninguno de los dos. (AGUILAR, 1986, p. 107).

En esta época la práctica del sexo interclasista formaba parte de la cultura de clase media, y la socialización en los lugares populares constituía un habitud de reafirmación: precisamente Novo (1946) registró en esos años una por entonces nueva práctica cultural nocturna "propia de las elites y clases medias con vocación bohemia, la cual consist(ía) en transitar de los escenarios de lo alto a los lugares de lo bajo" (NOVO, 1967, p. 55). El frecuentar los lugares de las clases populares ofrece a los homosexuales de clases acomodadas, al igual que a los demás hombres de éstas, la "sencilla ilusión de que son muy refinados y decadentes (...) creen divertirse con los pelados que, en realidad, son quienes se divierten con verlos" (NOVO, 1967, p. 56). (Imagen 1).

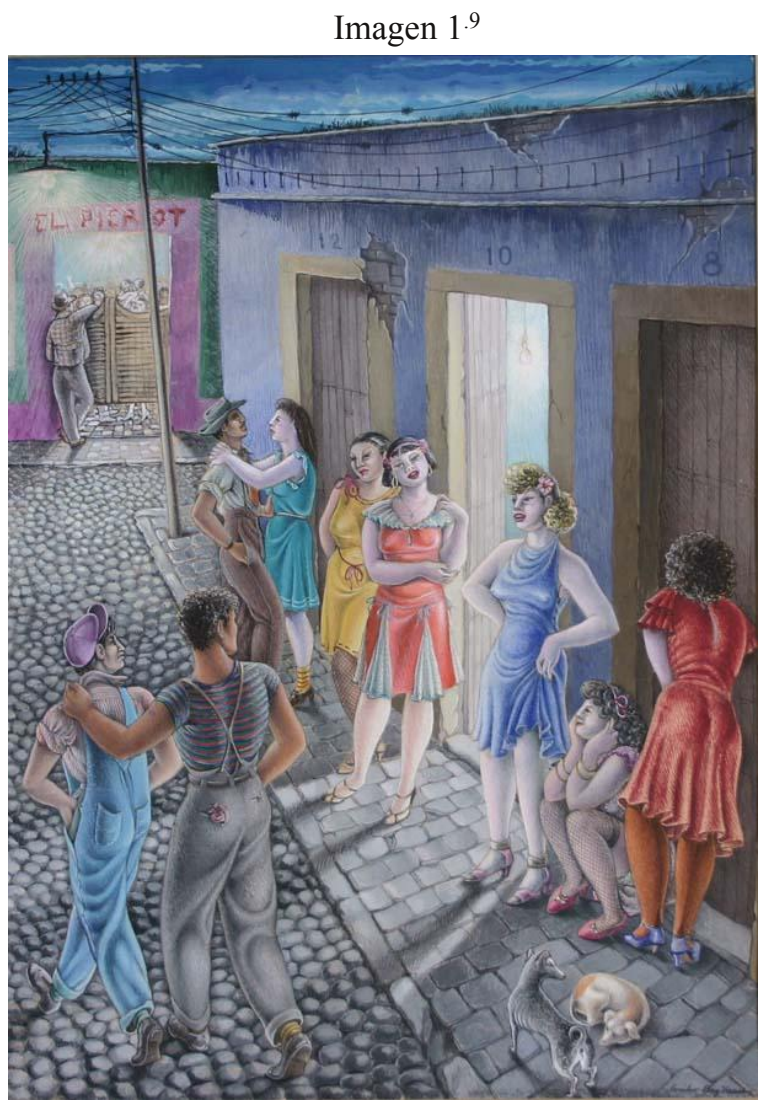

La desigualdad económica que empreña las relaciones de Nandino le asegura la posibilidad de preservar cierta superioridad - poder - ante sus novios, incluso de reafirmar su masculinidad, reproduciendo relaciones jerarquizadas y no exentas de sexismo. Por ejemplo, le ofrece casa a Orfeo cerca de la suya, para así ser "dueño de su tiempo, de su cuerpo, y de su vida" (NANDINO, 2000, p. 107). "Necesitaba sentir posesión respecto de la gente. Sin concepto de propiedad no podía amar a nadie" explica Nandino (AGUILAR, 1986, p. 104). Las relaciones de Nandino están marcadas por su posición social, por este deseo de posesión y dominación que Joaquín Blanco (1986, p. 63) describe en Los apetecibles cuerpos de la miseria: "para dominarla mejor, la clase pudiente ha sobre - erotizado los cuerpos de los jodidos; son solamente una posesión, un acto de apropiación".

La búsqueda de varones de rasgos muy masculinos, viriles, bisexuales, vueltos pasivos y refinados bajo sus manos, se complementa en Nandino por el rechazo a 'los afeminados' - Pellicer, Villaurrutia y Novo, del grupo de los Contemporáneos, entre otros - con quienes consigue su prestigio y su desprestigio (sic) "porque ya socialmente ellos estaban señalados como homosexuales" (NANDINO, 2000, p. XVI).

De ahí, quizás, que no frecuentara los lugares de reunión de ambiente - el café de chinos de Donceles, del cual huye como la peste (AGUILAR, 1986, p.119), o más tarde Los Eloines o El Eco, nunca mencionados en sus biografías- mientras que, en cambio, probablemente encontraba según sus gustos en los lugares más mixtos. En este sentido, la aparición, a mediados del siglo XX, de espacios exclusivamente 'de ambiente' puede leerse como una primera especialización de los lugares de ocio en función de los gustos y formas de vivir el homoerotismo de las clases más acomodadas. (Imágenes 2 y 3$)^{10}$.

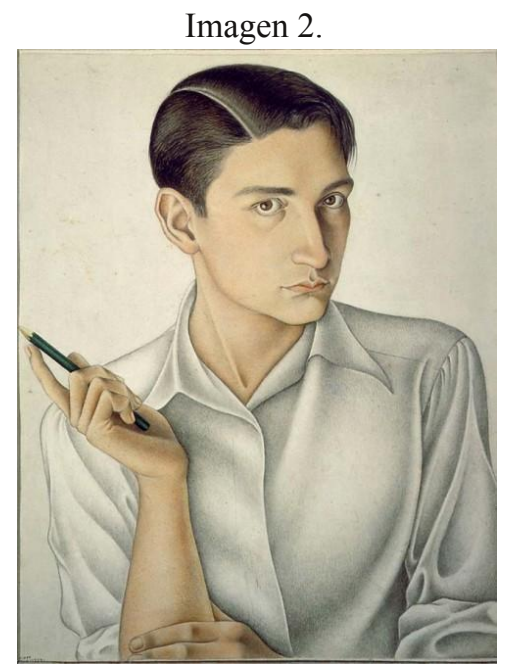

Renaud René Boivin 
Imagen 3.

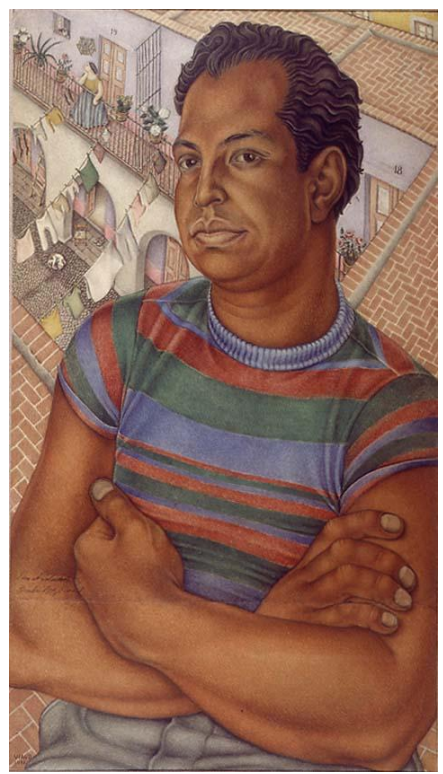

\section{Los Primeros Lugares Especializados}

A finales de los años 40 aparecen los primeros lugares comerciales especialmente destinados a una población homosexual y lesbiana: El Eco, en la calle Sullivan, L'Etui, en la esquina de la Avenida de Chapultepec y Calle Florencia, Los Eloínes (1951), propiedad de David Mont regentada por una pareja homosexual en la calle República de Cuba 45 - en frente del Teatro Lírico - así como el Madreselva (1949), "un cabaret pequeño donde los entendidos beben pero no bailan, ansían pero temen aventurarse más allá de lo verbal, más allá de lo admitido por el juego de la mano debajo de la mesa y el 'coito verbal'. Los asistentes temen las redadas y por ello llevan dinero extra". (MONSIVÁIS, 2002, p. 102).

Por otra parte, en los años 50 otros establecimientos, mixtos, se tornan centros de reunión conocidos de homosexuales y travestís: como El Paseo, en Reforma, de conexión entre turistas estadounidenses y jóvenes homosexuales trabajadores de hostelería; la cafetería del Hotel Regis, en la Alameda, donde se reunían famosos travestís y homosexuales junto con artistas, cineastas mexicanos y extranjeros:

Llegué a México en el 56. (...). Había más libertad que ahora. Los ataques siempre han existido. Había lugares más bonitos. De los que me acuerdo estaban: El Eloines, el Inde, el Belvedero del Hotel Hilton. Era dizque para las 'muy chicas'. Había otros como el Nicté - Ha ${ }^{l l}$. (Xochitl, travesti, empresario, entrevistada por Hernández y Manrique, 1984, CIDHOM).

Finalmente, algunos establecimientos de barrio, más discretamente, se suman a la trama de ligue y residencia homosexuales en las colonias Doctores, Roma y Cuauhtémoc: "Visto desde afuera el bar Chimu se parece a cualquier otra cantina, pero nada más entrar sabes que estás en un bar de maricas. Pedí una copa en la barra y miré alrededor. Tres maricones mexicanos hacían posturas delante de la máquina de discos", recordaría William Burroughs (citado en GONZÁLEZ, 1989, p. 54).

$\mathrm{La}$ aparición de estos primeros comercios especializados supone una evolución importante en los modos de vida de los homosexuales de las clases medias de la ciudad de México, destacándose su mayor separación de las clases populares en los lugares de ocio. Nos dice Samantha Flores, a propósito del 'Salón México' y de los lugares de la plaza Garibaldi, a mediados de los años 50: "es más el folclore que tenían porque eran de raspa, raspa raspa, raspa de raspa! ¡De ese grado eran! Tuve la suerte de conocer gente bien, ¿no? Desde que trabajé por la escuela hotelera. Así es que siempre estuve en esferas altas de la gente gay, de gente rica, muy rica".

El desplazamiento de los nuevos centros sociales homosexuales hacia el centro moderno, cerca del cruce entre Insurgentes y Reforma, parece iniciar tal separación: a mediados de los 50 el ambiente ya se concentraba en las colonias Cuauhtémoc y Juárez, signo de una visibilidad acrecentada. Ahí residían o se hospedaban en hoteles de lujo, asistían a cenas y fiestas privadas en las casas de las hermanas Inés y Pita Amor, famosos y ricos homosexuales.

\section{Represión y Depresión}

Así pues, a mediados de los años 50 el ambiente permeaba en ámbitos artísticos y círculos literarios, en las reuniones de actrices y cantantes, en la Condesa, Chapultepec, la Roma Norte. Florecía en los restaurantes, galerías de arte $^{12}$, estudios de pintura, centros nocturnos y cafés de moda. También se acrecentaban los crímenes contra homosexuales y bisexuales. El miedo crece a la par con la inseguridad, y los homosexuales empiezan a temer los ligues con el homo/bisexual moreno o 'mayate' (véase MONSIVÁIS, 2002). Según Monsiváis (2002; 2007), con el escándalo que suscitaron las muertes sangrientas de Mercedes Cassola y su amante bisexual 
en 1959, el regente de la ciudad, Uruchurtu (1954 1966), implicado en el asunto, endurece su postura.

$\mathrm{Su}$ política restrictiva y represiva respecto de la vida nocturna llevaría directa o indirectamente al cierre de muchos cabarets y cantinas de la ciudad, y en especial de los pocos lugares de reunión para lesbianas y homosexuales (GRUZINSKI, 1996; LAGUARDA, 2009). Xochitl confirma que hubo una fuerte represión (redadas, cierres de establecimientos) a raíz de aquel escándalo. Es decir: la mayor permisibilidad y el fortalecimiento del medio homosexual, su visibilidad pública, habrían llevado a reprimir y oprimir, invisibilizar y asesinar, a los homosexuales.

A principios de los años 60 , el viejo centro se había ido vaciando de los habitantes más acomodados, y su imagen se hallaba muy degradada por la cercanía de la llamada 'línea de tugurios', en las colonias Guerrero, Morelos y Buenavista (MONNET, 1994) ${ }^{13}$. El sismo de 1957, que afectará la Avenida San Juan de Letrán en varios puntos, algunos tramos del Paseo de la Reforma y la colonia Roma, además de numerosos cines y lugares emblemáticos, intensificó las dinámicas de abandono y degradación del parque habitacional así como la presión al desalojo hacia los inquilinos para liberar los edificios de las rentas congeladas.

El urbanismo moderno y el pensamiento acerca de la ciudad histórica reforzarán estas dinámicas de desplazamiento, abandono y despoblamiento: se trasladan las facultades de la UNAM a Ciudad Universitaria (1954), se inicia la construcción de un sistema viario moderno para crear movilidad y acercar las alejadas zonas residenciales al centro económicofinanciero. La ampliación de la Avenida Reforma hacia el Norte y la construcción del conjunto Nonoalco Tlateloco, junto con instrumentos de renovación urbana, se presentó como la vía perfecta para cortar entre los llamados tugurios y aportar una respuesta urbana a la concentración de pobreza y delincuencia. Dichos cambios incidirán en la configuración del ocio en la ciudad, con la destrucción de numerosos edificios, cabarets, hoteles y calles de la Colonia Guerrero. Cae gran parte de la vida prostibulera al desaparecer el Callejón del Órgano de La Región más transparente, y los tradicionales centros nocturnos entran en decadencia ${ }^{14}$, provocando a su vez la deserción de las mujeres que residían por el rumbo. Por otro lado, con las nuevas restricciones de horarios y actividades, cierran múltiples centros nocturnos y salones, el control policial aumenta y las redadas se hacen continuas. Alrededor de Garibaldi, quedaron algunas cantinas, cada vez más decadentes, cada vez más violentas.

\section{La Transición Homosexual en los años 60 y 70}

Al cerrar los primeros bares con una asistencia exclusiva de homosexuales y lesbianas, se multiplican los concursos travestis, orquestados por la 'reina' Xochitl en los salones, hoteles y restaurantes más lujosos de la ciudad, en compañía de hombres poderosos y adinerados a los que presentar a sus nuevas reclutas (entrevistas con Samantha Flores y Francisco Calderón, 2010 - 2011). La escasez de lugares posiblemente haya incentivado también la organización de fiestas en casas privadas, de las cuales el encuentro entre clases quedaba excluido. Es decir: una vez suprimidos los lugares más significativos del ocio nocturno, se transforman las estrategias espaciales de la nueva generación homosexual, cristalizándose tal cambio en espacios públicos, semi - públicos y privados de la ciudad a lo largo de los años 60 y 70 .

Se potencia la reapropiación por una minoría homosexual de la moderna Zona Rosa ${ }^{15}$ para transitar, socializar y ligar, en los cafés y en las calles adyacentes. Los trabajadores sexuales siguen la corriente del cliente potencial y se hacen más presentes en algunas esquinas, en los cafés Sanborns y sus alrededores, como quedó novelado en El Vámpiro de la Colonia Roma, de Luis Zapata. Por aquellos tiempos, Zona Rosa ya se ha convertido en un barrio de moda, sus calles y cafés son frecuentados por una minoría de artistas, escritores, periodistas, estudiantes y turistas. Representaba un "lugar neutro donde eran permisibles estas expresiones", era la "zona alternativa al Zócalo" afirma Juan Jacobo Hernández. Los primeros grupos del movimiento homosexual empiezan a reunirse en Zona Rosa para plantear debates y movilizarse. Por último, en ésta también se organizan y anuncian las fiestas privadas realizadas en propiedades de la Colonia del Valle, San Ángel y Coyoacán.

Según Guash (1995), la introducción del modelo gay de socialización supone la institucionalización de bares, saunas, discotecas, y la consecuente territorialización de la actividad de ligue homosexual. La calle, antes lugar fundamental para el encuentro homoerótico, espacio de aprendizaje de una subcultura sin lenguaje, pasa al segundo plano en las prácticas de la nueva generación homosexual, al volverse central el disco - bar en los modos de vida del gay urbano ${ }^{16}$.

Ahora bien, los cambios acaecidos en las formas de socialización homoeróticas conllevan también una concentración urbana de los nuevos lugares de encuentro y reunión. Y, en general, estos se nutren de la actividad de seducción, encuentro y socialización

Renaud René Boivin 
De Cantinas, Vapores, Cines y Discotecas.

Cambios, Rúpturas e Inercias en los Modos y Espacios de Homosocialización de la Ciudad de México

presente en la calle y se insertan en la trama residencial homosexual. En México, este movimiento es muy notable, al concentrarse los nuevos establecimientos alrededor de Zona Rosa. En efecto, los primeros disco - bares destinados a una población gay van ubicándose en la colonia Cuauhtémoc y en las calles paralelas a la Avenida Insurgentes Sur, acercándose progresivamente a la Colonia Juárez ${ }^{17}$.

Estos nuevos comercios se sitúan cerca de uno de los ejes principales de la ciudad, de proyección de la centralidad (MONNET, 1994), que vincula directamente el centro geográfico con las colonias residenciales del Sur y Ciudad Universitaria y los puntos de reunión de los grupos homosexuales en cafés y departamentos de las colonias Condesa, Roma y Cuauhtémoc. Asimismo, esta ubicación se relaciona con la cercanía de ligue callejero en la 'esquina mágica', así como de prostitución masculina en zonas cercanas. Es decir, los establecimientos comerciales surgen allá donde el "ambiente" se hacía presente desde algunos años atrás:

La colonia roma está llena de gente de ambiente yo creo que después de la cuauhtémoc ésta le sigue andas por la calle y a cada ratito te encuentras (...) uno dos tres quince cuates que tú ves que son de onda entons* 18 te sientes como en tu propia casa ¿no? Así como en una gran fraternidad. (ZAPATA, 2000, p. 52).

En 1977, El 9, un bar gay de moda por muchos años, inicia finalmente su actividad en el corazón de Zona Rosa, en un lugar muy estratégico. Unos años más tarde, abrirá L'Baron cerca del Parque Hundido, aprovechándose tanto del tejido residencial gay de la zona como de menores restricciones de la delegación en términos de horarios ${ }^{19}$. Esta reaparición de lugares comerciales frecuentados por una población específicamente homosexual se da en el marco más amplio de una profunda transformación de la vida cultural y nocturna, con la introducción del concepto estadounidense de discoteca.

La vida social homosexual seguía girando en torno al binomio ya tradicional desde los años 20, formado por el café y la cantina, relacionados con la conversación y el ligue discreto. Los establecimientos como El Reno's, El Don o Mío Mundo continuaban ofreciendo un servicio acorde con aquella manera más tradicional, de restorán - cantina, donde se podía tomar y hablar pero más difícilmente bailar en pareja, y el Safari era un lugar de mezcla e interacción bisexual. Los lugares tales como El 9 o L'Baron se tornan en cambio una novedad al articular un nuevo modelo de disco - bar en donde el baile se vuelve la actividad central y los 'gays' los protagonistas principales:

El Safari tenía tres sectores perfectamente definidos: el lado sur (la Caldera del Diablo), ocupado exclusivamente por hombres homosexuales, el norte (el Cuadrante de Lesbos), por lesbianas, y el centro por una mezcla de concurrentes heterosexuales y cuatro o cinco prostitutas que lo mismo aceptaban hombres o mujeres. (MARTRE, 1970).

(...) rompían con lo que era el modelo común de aquella época, que era por ejemplo un café por ahí mexicano que estaba en avenida Chapultepec, L'Etui. Era un restaurancito frecuentado por gente de ambiente. $Y$ curiosamente un bar un poquito más audaz, básicamente de lesbianas, el Safari en la ya famosa Zona Rosa que había emergido desde los 60. (Mondragón).

Cuando me mudé en un departamento por el Parque Hundido, ahí descubrí L'Baron. Como podía llegar a pie aunque estuviera ahogado de borracho, iba siempre ahí. Ese fue mi descubrimiento de un bar-disco gay, porque los otros no eran discos, eran cafecitos muy monos; muy sentadito, pedías la copa y platicabas y ya. (De Alba)

La nueva generación se va alejando de las cantinas tradicionales del centro, vistas como insalubres, anticuadas, degradantes para un homosexual de clase media:

Los demás lugares eran muy feos, porque casi siempre eran propiedad de heterosexuales que pensaban que si iban a tener un bar para jotos, entonces tenían que poner manteles de color de rosa y moños. Pensaban que los homosexuales eran así, además que el trato era a patadas. Eran lugares verdaderamente siniestros. (De Alba).

No había muchas opciones de diversión, de no ser una cantina de arrabal en la calle de Independencia -casi esquina con Lópezllamada El Villamar. No era un sitio al que fueran comúnmente los güeritos, bien vestidos y peinados de la clase media y alta 
(...). Más bien era un antro al que iban obreros, taxistas, camioneros, vestidas y gente de los barrios bajos del centro de la ciudad. Lugares así no eran una opción del todo entretenida para un chico como yo o como mis amigos (...), de clase acomodada y acostumbrados a convivir en ambientes menos sórdidos. (CALDERÓN, 2008).

González de Alba abrirá primero El Vaquero, a dos pasos de L'Baron, con una estética a las antípodas de las cafeterías y 'bares de jotos', y una trastienda que hacía oficio de sex - shop y donde vendía artesanías reivindicativas y de poses provocativas. Prohibió la entrada a mujeres y travestís. Abrió finalmente El Taller en la calle Florencia $\mathrm{n}^{\circ} 37$, cerca de El 9, aprovechando la coyuntura inmobiliaria tras los sismos de 1985. Promovió u obligó a llevar jeans y camisetas de tirantes. Los shows no eran de travestís y transexuales, sino de hombres de cuero y aspecto viril. Todo esto a unos pasos del Ángel de la Independencia: lo marginal había llegado al centro.

Así pues, la 'transición homosexual' en parte rompe con una cultura homosexual más interclasista al desalojar al gay de la calle y de los espacios mixtos. Los establecimientos más populares del centro se abandonan progresivamente, al no corresponder la representación (más tradicional) y vivencia (más ambigua) de la homosexualidad con la imagen que los gays de clases superiores (profesionistas, artistas y literatos) tienen o quieren dar de sí - mismos. El desplazamiento hacia zonas de mayor prestigio está a su vez vinculado a la formación de nuevos valores, al establecimiento de nuevas maneras de entender y vivir las relaciones homoeróticas, al impacto de la diferenciación social en la definición de la sexualidad. La nueva generación, al buscar romper con un conjunto de estereotipos y valores tradicionales acerca de las relaciones de género y de la homosexualidad, reafirmaría una vez más las barreras de clase, como bien presagió Blanco en Ojos que dan pánico soñar (1979). El 'gay' se define por el rechazo a las características que el discurso dominante y tradicional vinculaba con la

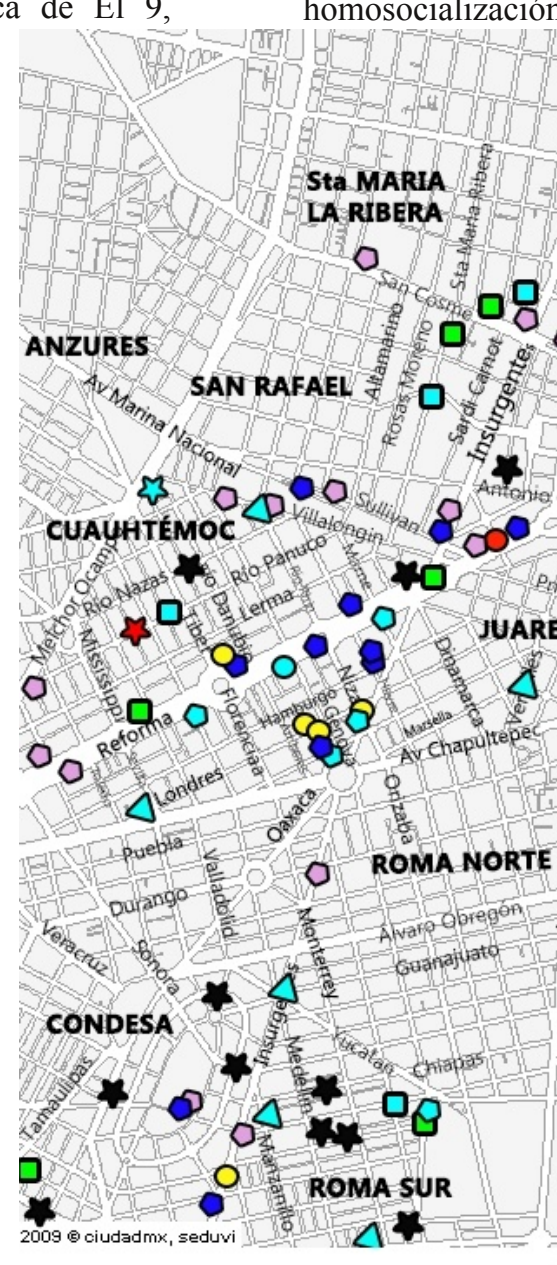

Mapa 2. El disco-bar gay y la nueva geografía de homosocialización en la ciudad de México, 1970-1980.

Los gañanes verdaderos, los realmente pobres, no eran la especialidad de la Gorda; le resultaban muy tímidos, como que no le entraban bien a la onda gay, que era como una rareza más de los ricos. Los sabrosos gañanes eran los disfrazados, los proletas artificiales. (BLANCO, 1983, p. 65).

, promiscuidad - por el social: virilidad y dinero. La masculinidad construida por el 'gym' y una dieta controlada desplaza el ideal homosexual del jodido obrero:

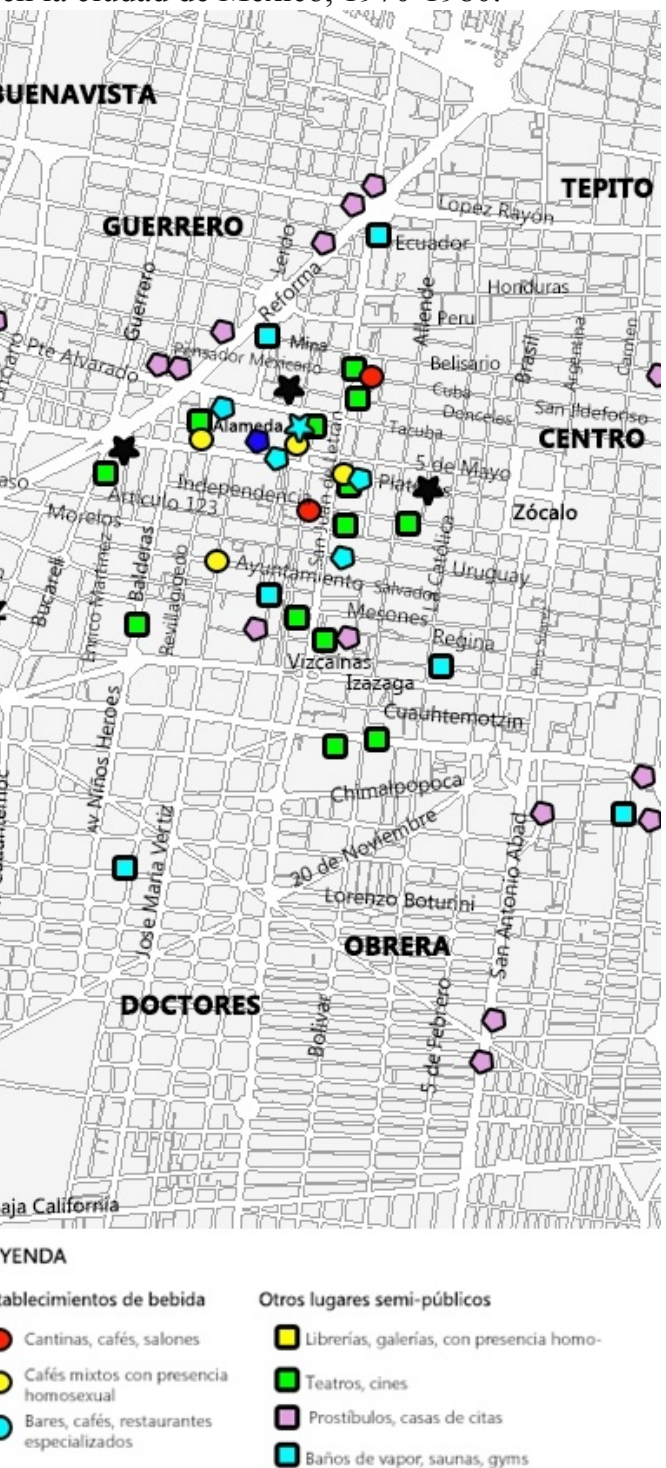

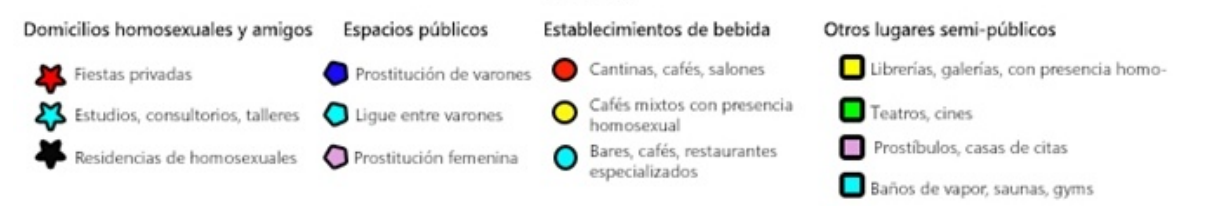




\section{Socialización y Culturas Homosexuales}

En Las púberes caneforas (1983), el escritor evidencia la existencia de dos mundos homoeróticos contrapuestos - aunque nunca separados - a través de la relación de Guillermo, burócrata de 40 años y Felipe, un joven bisexual y chichifo $^{20}$ de quien se enamora. Guillermo se caracteriza por su gran movilidad, ligada a su posición social: puede pasar de los salones mixtos, frecuentados por senadores, periodistas y familias adineradas, a la aventura arriesgada de la Alameda y de las calles abandonadas del Centro, donde siempre acaban los últimos pasos del 'callejoneo' en su 'búsqueda de nuevas, más sucias y escondidas cantinas ilegales, con putas y chichifos cada vez más agrios, enfermos, viejos" (BLANCO, 1983, p. 36).

Sin embargo, por muy fácil que le sea franquear las distancias socio - geográficas, no consigue acercarse y enseñarle a su amante, de clase baja, a ser 'gay', a adoptar una cultura sexual ya no basada en el intercambio material (a la Nandino) o en la mera amistad, sino en la reciprocidad y el amor. Los deseos de noviazgo y relación formal de Guillermo no pueden ser satisfechos con el joven chichifo. No tanto porque las condiciones sociales no se lo permitan, sino porque Felipe no entiende las relaciones homosexuales en los mismos términos: "Y toda esta gelatina emotiva sin la cual Guillermo no se resignaba a acercarse al sexo. Esos ojos vidriosos y esos gestos conmovidos no eran sino ganas, que Guillermo no podía aceptar como tales (...), porque se siente tan civilizado y superior" (BLANCO, 1983, p. 76).

Sin embargo, el relato de Blanco también evidencia la persistencia, contradictoria a la vez que complementaria, de formas de encuentro social y sexual entre clases y grupos, en espacios públicos y cantinas populares del viejo centro. Existe cierta inercia social y hasta geográfica en los modos de vida $\mathrm{y}$ formas de encuentro de los varones que mantienen relaciones sexo - afectivas con hombres en la ciudad de México: el vagabundeo, el sexo anónimo e interclasista, la aventura nocturna en busca de un compañero efímero, la clandestinidad y la oscuridad, la búsqueda imposible de la pareja estable, forman parte de una memoria homoerótica sin palabras, que se repite en los actos individuales generaciones tras generaciones. Estas condiciones no se deben a la falta de visibilidad o a la represión de la homosexualidad: están ligadas a los modos de construcción sexo-erótica de los varones capitalinos.

En efecto, en dicha construcción la calle, la oscuridad, la clandestinidad, las diferencias socioétnicas, los juegos de luz y sombras, constituyen polos de excitación, deseo y/o placer. El espacio público es reconocido como lugar apropiado para la seducción y la relación sexual ${ }^{21}$. Sin duda dichas formas de socialización y encuentro han sido asociadas desde antaño a unas fantasías sexuales clasistas de clase media. "Las cosas prohibidas que calientan al burgués: relación sexual con diferentes clases, prácticas sexuales no engendradoras, explosiones violentas del cuerpo encorsetado todo el tiempo en la forma burguesa; cínicas expresiones del deseo de posesión y de poder, manifestaciones de brutalidad", afirma Joaquín Blanco, quien precisa: "La civilización burguesa se excita precisamente con lo que reprime legalmente; sueña con lo que ella misma reprime" (BLANCO 1986, p. 71).

Puede que se vincule, también, con una tradición histórica y local de mezcla entre sectores sociales y grupos étnicos. Se entiende así por qué la aparición de lugares especializados, vinculada a las estrategias de reproducción de las clases acomodadas de la ciudad, sólo rompe de manera parcial con la práctica de espacios más mixtos en términos socio-culturales y de sexualidad, de la misma manera que la asunción de una cultura homoerótica moderna (LAGUARDA, 2009), no borra la variedad de las experiencias homoeróticas, ni acaba con las culturas sexuales más tradicionales, indefinidas y ambiguas.

\section{Conclusiones}

Tanto en los años 20 y 30 como en los años 50 y 60 , por muy estigmatizadas que fueran las relaciones sexuales entre varones, los 'homosexuales' no dejaban de ser 'visibles' en el espacio urbano. De hecho, en reiteradas veces a lo largo de la historia urbana de México, la aparición de lugares específicos fue asociada al aumento del control policial, a la insistencia de la corrupción de los gobiernos locales o a la misma inseguridad. Por tanto, no se puede entender el disco - bar gay, la llegada de una cultura homosexual urbana, como ilustraciones de la liberación sexual y/o de la liberalización económica de la capital. Cabe matizar las interpretaciones expresadas en términos de represión, invisibilidad y liberación, y entender el 'clóset' como una estructura simbólica e histórica de construcción relativamente reciente.

Asimismo, la transformación de los lugares de socialización en la ciudad de México debe ser estudiada a un nivel más fino para evitar errores de interpretación histórica que hagan pensar que las condiciones de vida homosexuales siempre fueron asociadas al ocultamiento y a la represión, o que intenten demostrar que los modos de vida $y$

\section{Renaud René Boivin}


representaciones identitarias gays actuales son necesariamente más progresistas que las formas del pasado.

Más que la falta de visibilidad, llama la atención el silenciamiento alrededor de las formas de socialización, la sexualidad, la fuerte presencia urbana, de homosexuales de buena reputación, que desde lustros han acompañado la formación de un clóset moderno en México. Finalmente, en el contexto de la ciudad de México, es necesario corregir también la propuesta de Guash, admitiendo que la calle, los lugares públicos, además de la trama urbana de residencias y estudios, talleres, consultorios, teatros y cines, cantinas, cafés y bares, formaban - y siguen formando - un entramado de interacciones sobre el cual se solidificaron e institucionalizaron los lugares especializados de homosocialización.

1 Centro de Información y Documentación sobre las Homosexualidades de México 'Ignacio Álvarez', albergado en el Colectivo Sol A.C. hasta 2012. Hoy forma parte del Centro Académico de Nuestra Memoria de América de la UACM.

2 En México, si bien se admite que la gaydad es construida desde las clase medias acomodadas, muy pocos estudios se interesan por entender las maneras en que la clase social, la posición socio-económica, pueden influir en las prácticas e identidades sexuales o por el homoerotismo en las clases populares.

3 Monsiváis (1998a, 2002) recurre a esta noción en varias ocasiones: "Para los homosexuales, su espacio ha sido el Ambiente, el gueto (la sociedad por ellos constituida, sin otras reglas que el ligue constante y la creación de 'familias gay' o núcleos amistosos)". (MONSIVÁIS, 1998a, p. 30).

4 A las entrevistas del Archivo Histórico del Movimiento Homosexual, proyecto de la ENAH y del Colectivo Sol A.C. (2004), se sumaron las realizadas por mí en 2010-2011. Salvo indicaciones contrarias, las citas incluidas en este artículo provienen de dichas entrevistas.

5 En esta misma sala, en calle Santa Veracruz $\mathrm{n}^{\circ} 19$, Colonia Guerrero, a principios de siglo se exhibieron clandestinamente las primeras películas eróticas, según evocan Leal et al. (2005).
$6 \quad$ En los mapas no se distinguen las dos funciones -de socialización o encuentro sexualcumplidas por cada sala de cine. En general, los cines convertidos en lugares de ligue y sexo entre varones a partir de los años 60 venían siendo salas significativas para los modos de vida y socialización homosexuales anteriormente, en especial las situadas en zonas de ligue (Alameda, San Juan de Letrán, Paseo de la Reforma).

7 Puede que Las Adelas o Las Adelitas, como se llaman a los militares que mantienen prácticas homoeróticas, haya sido un sobrenombre para referirse a distintos lugares de la zona. De momento, no he reparado ninguna referencia a Las Adelas en los escritos de Novo y Nandino. El único lugar conocido con este nombre era el Bar 14, situado a un costado de Garibaldi en los años 90, y que Monsiváis (1998b) describió.

8 Según González Rodríguez (1989), hasta 1983, ninguna mujer no acompañada, que no fuera para trabajar (de fichera) podía penetrar en una cantina.

9 La calle de Cuauhtémotzin, representada por Emilio Baz en 1941. La presencia de la cantina al fondo, el gesto afectivo del varón de piel más oscura es una referencia autobiográfica directa a su 'amistad especial' con 'El Hotentote', según se entendía en la época la camaradería sexual entre dos varones. Imagen: Colección A. Blaisten: www.museoblaisten.com

10 Imágenes 2 y 3: Autorretrato (1935) de Emilio Baz Viaud, con 17 años, proveniente de una familia adinerada, y El Hotentote (1941), retrato de José Antonio Gómez Rosas, su pareja sentimental, quien vivía en el barrio de la Merced, representado a su espalda. Ex alumno de la escuela de pintura La Esmeralda, escenógrafo, animador y decorador de fiestas de máscaras, famosos teatros y salones. El pintor insiste en los rasgos viriles e indígenas y la vestimenta popular de su amante, características a las que debe su sobrenombre. Imágenes: Colección A. Blaisten: www.museoblaisten.com

11 Xochitl se refiere a los cabarets del Hotel Continental-Hilton, en Reforma e Insurgentes, y del Hotel del Prado. En el Hotel Reforma se situaba el Ciro's y el Hotel Regis de la Alameda también contaba con cabaret propio. Se trataba de lugares más permisivos por la presencia de turistas internacionales. 
La travesti subraya que en éstos - a diferencia de los situados en plaza Garibaldi y Colonia Guerrero acudían las travestís y los más afeminados ('las muy chicas').

12 La galería de Daniel Mont y Gabriel Orendáin, pareja homosexual de mecenas, en Puebla $\mathrm{n}^{\circ} 154$ (Colonia Roma) era por ejemplo un lugar importante de reunión y formación de redes del "ambiente". La Galería de Arte Mexicano, de Inés Amor, situada en Milán $n^{\circ} 18$ (Colonia Juárez) o la casa-estudio de Chucho Reyes Ferreira, homosexual tapatío, en Milán $n^{\circ} 20$, representaban también lugares mixtos de socialización entre varones. (NEUMAN, 1993; MANRIQUE y DEL CONDE, 2005).

13 La visión del viejo centro es tan negativa, que en 1971, Salvador Novo, quien había sido un gran cronista de éste, para no toparse con la violencia callejera, se negará a acudir a la cena de su amigo homosexual David Antón en su penthouse de la calle Madero (NOVO, 1994).

14 Según indica González Rodríguez (1989) en 1957 fueron desalojadas de la calle del Órgano. Carlos Fuentes proporcionó el último retrato del callejón antes de las obras.

15 Zona Rosa es el sector más comercial de la Colonia Juárez, a unos pasos del barrio financiero de Reforma. La colonia Juárez fue urbanizada a principios del siglo XX, con una arquitectura de estilo francés y neoclásico. Forma parte de la delegación central del Distrito Federal - Cuauhtémoc. Las colonias Roma, Condesa y Cuauhtémoc bordean la Juárez.

16 El estudio de Gallego (2010) evidencia que el disco-bar se ha vuelto central en los modos de vida y socialización de las jóvenes generaciones. Los encuentros socio-sexuales tienen lugar en espacios comerciales principalmente.

17 Los establecimientos abiertos entre finales de los 60 y 1980 fueron Safari (1965?); Penthouse, pub clandestino de Donnadieu en el piso 15 del no 100 de la calle Manzanillo, entre 1975 y 1977; D’Val, en Baja California, dirigido por Martha Valdespino y animado por Samantha Flores (1976-1979?); Bagoas, en la calle Monterrey, esquina con Chiapas. A principios de los 70 , en la calle Durango, casi esquina con Insurgentes, se inauguró el restaurante Las Canastas de la misma dueña que el Reno's en Reforma n²76. Mío Mundo, ubicado en calle Bucareli, abrió en 1974. Por esos años durante unos meses funcionó Camelia la Texana en San Ángel. El Don abrió a principios de los 70 . (CALDERÓN, 2008; entrevistas CIDHOM y entrevistas personales con Samantha Flores y Paco Calderón). En el mapa se distingue entre los distintos tipos de establecimientos.

18 Entons: abreviatura de Entonces en algunos países Latino Americanos.

19 El Mapa 2 no representa varios focos residenciales, comerciales y de ligue en el sur: en Tacubaya, en la Colonia del Valle y alrededores y en San Ángel vivieron varias figuras del ambiente de los años 60 y 70, y existían varios lugares "gays". Ciudad Universitaria, y en especial la Facultad de Filosofía y Letras, representaba otro foco de actividad política del movimiento, de encuentro y sexo entre varones desde años los años 60.

20 En México se usa el término 'chichifo' para designar al varón que ejerce la prostitución con otros varones, de manera profesional o esporádica.

21 Estas formas clandestinas y callejeras del encuentro homosexual han sido descritas como el reflejo de la marginación homosexual, por las situaciones de corrupción y violencia que engendraban. Novo vinculaba las relaciones anónimas con el desamor y la soledad: "La ley de la demanda y de la oferta/que se me ha enseñado su sabiduría/lleva el fácil amor hasta mi puerta/Y sin embargo, a veces, todavía/Sobre el crespón de mi esperanza muerta/vierte su llanto la melancolía" (Sonetos, citado por Monsiváis, 1997, p. 25). “¿Qué es la sordidez, aquello alejado de las luces de la respetabilidad, lo que impulsa al contacto íntimo con desconocidos, a la aventura riesgosa, a la inminencia del chantaje y el arresto, a las turbias recompensas de la adrenalina, al abandono por unas horas de la personalidad de todos los días (...) ?", se pregunta a su vez Monsiváis (2002, p. 112), quien vincula entonces la oscuridad con el closet. En contraste, en Francia la "homosexualidad negra", popular, de encuentros en baños, parques y calles, entre distintas clases sociales e inter-étnicas, ha sido retratada de manera más positiva por los literatos, en especial Marcel Proust y Jean Genet. 


\section{Referencias}

AGUILAR, Enrique. Elías Nandino. Una vida no/velada. México: Grigalbo, 1986.

ALFARO SALAZAR, Francisco Haroldo; OCHOA VEGA, Alejandro. Espacios distantes aún vivos. Las salas cinematográficas de la ciudad de México. México: UAM-X, 1997.

BLANCO JOAQUÍN, José. Las púberes canéforas. México: Ediciones Océano, 1983.

BLANCO JOAQUÍN, José. Función de medianoche. México: Ediciones Era, (1979), 1986, p. 71 - 73 / 184 $-189$.

BOIVIN, Renaud. De la ambigüedad a la sobrevisibilidad: homosexualidad, género y espacio en la Ciudad de México. Ciudades. Análisis de la coyuntura, teoría e historia urbana, n. 88, p. 52 - 59, 2010 .

BOIVIN, Renaud. Del clóset al gueto gay: París, Madrid y México. La Ventana, n. 34, p.146 - 189, 2012.

CALDERÓN, Francisco. ¿Quién fue Jaime Vite?. [Disponible en: www.gaymexico.mx] 2008.

DE LA COLINA, José. Recuerdo del Cinelandia. Milenio. 25 de junio de 2011. [Disponible en: http://www.milenio.com/cdb/doc/impreso/8981746].

GONZÁlEZ RODRÍGUEZ, Sergio. Los bajos fondos. El antro, la bohemia y el café. México: Cal y Arena, 1989.

GONZÁLEZ RODRÍGUEZ, Sergio. El secreto y el estudio. Nexos, n. 165, s/p, 1991.

GRUZINSKI, Serge. Histoire de Mexico. París: Fayard, 1996.

JIMÉNEZ, Armando. Cabarets de antes y de ahora en la ciudad de México. México: Plaza e Valés, 1991.

LAGUARDA RUIZ, Rodrigo. La emergencia de los bares gays en la ciudad de México: el espacio como generador de identidad. En: DEL CARMEN COLLADO, María. Miradas recurrentes. La ciudad de México en los siglos XIX y XX. México: Instituto Mora/UAM, 2004, p. 311 -319.

LAGUARDA RUIZ, Rodrigo. Ser gay en la ciudad de México. Lucha de representaciones y apropiación de una identidad, 1968-1982. México: Instituto Mora/CIESAS, 2009.

MACÍAS-GONZÁLEZ, Víctor Manuel. Entre lilos limpios y sucias salesas: la homosexualidad en los baños de la ciudad de México, 1880-AGUILAR, Enrique. Elías Nandino. Una vida no/velada. México: Grigalbo, 1986.

ALFARO SALAZAR, Francisco Haroldo; OCHOA VEGA, Alejandro. Espacios distantes aún vivos. Las salas cinematográficas de la ciudad de México. México: UAM-X, 1997.

BLANCO JOAQUÍN, José. Las púberes canéforas. México: Ediciones Océano, 1983.

BLANCO JOAQUÍN, José. Función de medianoche. México: Ediciones Era, (1979), 1986, p. 71 - 73 / 184 $-189$.

BOIVIN, Renaud. De la ambigüedad a la sobrevisibilidad: homosexualidad, género y espacio en la Ciudad de México. Ciudades. Análisis de la coyuntura, teoría e historia urbana, n. 88, p. 52 - 59, 2010.

BOIVIN, Renaud. Del clóset al gueto gay: París, Madrid y México. La Ventana, n. 34, p.146 - 189, 2012.

CALDERÓN, Francisco. ¿Quién fue Jaime Vite?. [Disponible en: www.gaymexico.mx] 2008.

DE LA COLINA, José. Recuerdo del Cinelandia. Milenio. 25 de junio de 2011. [Disponible en: http://www.milenio.com/cdb/doc/impreso/8981746].

GONZÁlEZ RODRÍGUEZ, Sergio. Los bajos fondos. EI antro, la bohemia y el café. México: Cal y Arena, 1989.

GONZÁLEZ RODRÍGUEZ, Sergio. El secreto y el estudio. Nexos, n. 165, s/p, 1991.

GRUZINSKI, Serge. Histoire de Mexico. París: Fayard, 1996.

JIMÉNEZ, Armando. Cabarets de antes y de ahora en la ciudad de México. México: Plaza e Valés, 1991.

Del Carmen Collado, María. Miradas recurrentes. 
De Cantinas, Vapores, Cines y Discotecas.

Cambios, Rúpturas e Inercias en los Modos y Espacios de Homosocialización de la Ciudad de México

La ciudad de México en los siglos XIX y XX. México: Instituto Mora/UAM, 2004.

MIANO BORRUSO, Marinela; Juan Jacobo HERNÁNDEZ; GUTIÉRREZ MAMOLEJO; Javier, (Comps). Archivo Histórico del Movimiento Sexual en México (CD). México: Centro de Información y Documentación sobre las Homosexualidades en México "Ignacio Álvarez"/ENAH/Colectivo Sol, 2004.

MANRIQUE, José-Alberto; DEL CONDE, Teresa. Una mujer en el arte mexicano. Memorias de Inés Amor. México: UNAM-IIE, 2005.

MARTRE, Gonzalo. Safari en la Zona Rosa. México: Editorial Mylsa, 1970.

MONNET, Jérôme. Usos e imágenes del centro de la Ciudad de México. México: DDF/CEMCA, 1994.

MONSIVÁIS, Carlos. Los que tenemos unas manos que no nos pertenecen. Debate Feminista, v. 16, n. 8, p. 11-33, 1997.

MONSIVÁIS, Carlos. Los espacios marginales. Debate Feminista, v.17, n. 9, p. 20-38, 1998a.

MONSIVÁIS, Carlos. La noche popular: paseos, riesgos, júbilos, necesidades orgánicas, tensiones, especies antiguas y recientes, descargas anímicas en forma de coreografías. Debate feminista, v. 18, n. 9, p. $55-73,1998 b$.

MONSIVÁIS, Carlos. Los gays en México: la fundación, la ampliación, la consolidación del ghetto. Debate Feminista, v. 26, n. 13, p. 89-115, 2002.

MONSIVÁIS, Carlos. Pasiones a la orden. La Ciudad de México y la cultura 1900-1950. Andes, n.17, 2006. [Disponible en: http://redalyc.uaemex.mx/pdf/127/12701711.pdf].

MONSIVÁIS, Carlos. De la variabilidad de la experiencia homoerótica. Debate Feminista, año 18, vol.35, p. 163 - 192, 2007.

MULIA, Rafael. De vapores y sudores. Baños El Chopo. El horizontal. México, 15 abril 2012. [Disponible en: http://www.elhorizontal.com/2012/04/de-vapores-ysudores-banos-el-chopo/].

NANDINO, Elías. Juntando mis pasos. México:
Editorial Aldus, 2000.

NEUMAN, Alma. Always Straight Away. A Memoir. Louisiana State University Press, 1993.

NOVO, Salvador. La vida en México en el periodo presidencial de Luís Echevarría. México: INAH/Estudio Salvador Novo A.C, 1994.

NOVO, Salvador. Nueva grandeza mexicana, México: Ediciones Era, 1967 (1946).

NOVO, Salvador. La estatua de sal. México: Ediciones Era, 2004.

LEAL, Juan Felipe et al. El cine y la pornografía. Anales del cine en México, 1985-1911. Vol. 7. México: Voyeur, 2005.

ZAMORANO, Beatriz. Manuel Rodríguez Lozano. Una interpretación finisecular. [Disponible en: http://www.islaternura.com/APLAYA/NoEresElUnico/ R/RO/RodriguezLozanoManuel/RodriguezLozanoFIN ISECULAR.htm, (consultado el 15 de junio de 2012).

ZAPATA, Luís. EI Vampiro de la Colonia Roma. Las aventuras, desaventuras y sueños de Adonis García. México: Debolsillo, 2006 (1979).

Recebido em 11 de agosto de 2012. Aceito em 17 de janeiro de 2013. 